\title{
ОСОБЛИВОСТІ ПЕРЕБІГУ ЗОВНІШНЬОГО ДИФУЗНОГО ОТИТУ ПРИ АТОПІЧНОМУ ДЕРМАТИТІ
}

\author{
๑о. Є. Кононов, І. Я. Пугач \\ Національна медична академія післядипломної освіти імені П. Л. Шупика
}

РЕзюМЕ. Дифузне запалення зовнішнього слухового проходу - дифузний зовнішній отит (ДЗО) досить поширене захворювання вуха. 3 ним стикаються як лікарі-отоларингологи, так і лікарі загального профілю. Етіологічні чинники можуть бути різноманітними: аеробна, анаеробна флора, гриби. Іноді ДзО бувають на тлі атопічного дерматиту (АД) у дітей. АД пов'язаний з підвищеною бактеріальною колонізацією та інфекцією шкіри. Захворювання має двобічну локалізацію, рецидивний перебіг та залежить від загострення атопічного дерматиту. Бактеріальні посіви виділень виявляють постійну зміну флори, залежно від проведеного лікування. Ми обстежили і пролікували 2 хворих на поєднану патологію. В обох випадках проведено лікування місцевими комбінованими препаратами. Отже, своєчасна діагностика цього різновиду дифузного зовнішнього отиту на тлі атопічного дерматиту дозволяє провести адекватну терапію.

КЛючОВІ СлОВА: дифузний зовнішній отит; атопічний дерматит; сімейний лікар; діти.

Вступ. Дифузне запалення зовнішнього слухового проходу - дифузний зовнішній отит (ДЗО) досить поширене захворювання вуха $[1,2] .3$ ним стикаються як лікарі-отоларингологи, так і лікарі загального профілю. Етіологічні чинники можуть бути різноманітними: аеробна, анаеробна флора, гриби. Захворювання частіше трапляється у теплий період року, після купання у забрудненій воді [3]. Клініка зазвичай досить типова: гіперемія, набряк шкіри, звуження слухового проходу, наявність виділень у ньому. Хворі часто скаржаться на сильний біль, зниження слуху. Іноді, при тривалому перебігу, підвищується температура тіла до субфебрильних цифр $[4,5]$. Іноді ДЗО бувають тлі атопічного дерматиту (АД) у дітей. АД пов'язаний з підвищеною бактеріальною колонізацією та інфекцією шкіри. Двобічність процесу обов'язкова. Біль та підвищення температури тіла відсутні навіть при довготривалому перебігу. Дитина не має скарг або є невеликий свербіж. Діагноз встановлюють при випадковому огляді сімейного лікаря або лОР-лікаря у зв'язку зі скаргами з боку інших лОР-органів. Іноді батьки звертають увагу на виділення з вух у дітей. Захворювання має двобічну локалізацію, рецидивний перебіг та залежить від загострення атопічного дерматиту. Бактеріальні посіви виділень виявляють постійну зміну флори, залежно від проведеного лікування. При отоскопії барабанна перетинка має червоний колір, потовщена, мутна, світловий конус вкорочений. Тому потрібно проводити диференційну діагностику з гострим середнім перфоративним отитом. У загальному аналізі крові відсутні ознаки бактеріального або вірусного запалення. Іноді $\epsilon$ еозинофілія [6, 7].

Приклад 1. Хворий О., 1 рік 1 міс., батьки звернулися 16.04.2019 р. зі скаргами на гнійні виділення з обох вух та неспокій дитини. Температура тіла не підвищувалась, нежить та кашель були відсутні. Дитина мала супутній діагноз атопічний дерматит та перебувала на лікуванні у алерголога. При отоскопії AD=AS: шкіра зовнішнього слухового проходу потовщена, гіперемійована, велика кількість рідкого гнійного вмісту. Після туалету слухового проходу 3 \% розчином перекису водню барабанна перетинка гіперемійована, потовщена, не перфорована, світловий конус не визначається. Риноскопія та фарингоскопія без патології. Аналіз крові:

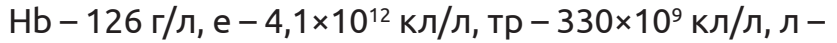
$6,3 \times 10^{9}$ кл/л, п- $2 \%$, с - $37 \%$, е - $2 \%$ л л $51 \%$, м 8 \%. При бактеріологічному посіві виділень з вух висіяний St.aureus. Діагноз: гострий двостороній зовнішній отит, гострий двостороній мірингіт.

Приклад 2. Хвора Г., 14 років. Направлена до отоларинголога сімейним лікарем після профілактичного огляду. Скарги на невеликий свербіж вух. В анамнезі наявний атопічний дерматит. При отоскопії AD=AS: зовнішній слуховий прохід звужений, гіпермійований, щільно заповнений білими масами. При промиванні розчином антисептика вимита значна кількість білувато-сірих виділень з різким неприємним запахом. Барабанна перетинка мала червоний колір, мутна, світловий конус вкорочений. Риноскопія та фарингоскопія без патології. Аналіз крові: Нb - 110г/л, е - 4,5×1012 кл/л,

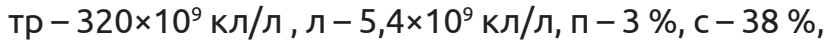
е - $12 \%$, л - 43 \%, м - 4 \%. При бактеріологічному посіві виділень з вух висіяні Kl. pneumoniae та Aspergillus. Діагноз: гострий двостороній зовнішній отит, гострий двостороній мірингіт.

В обох випадках проведено лікування місцевими комбінованими препаратами. Отже, своєчасна діагностика цього різновиду дифузного зовнішнього отиту на тлі атопічного дерматиту дозволяє провести адекватну терапію. 
Огляди літератури, оригінальні дослідження, погляд на проблему, випадок з практики, короткі повідомлення ЛІТЕРАТУРА

1. Федотова О. В. Современный взгляд на лечение диффузного наружного отита / О. В. Федотова, Г. Б. Шадрин // Вестник оториноларингологии. - 2016. - Т. 81, № 3. - С. 51-53.

2. Пионтковская М. Б. Хронические наружные отиты: вопросы спортивной профпатологии у детей и подростков / М. Б. Пионтковская, Ю. В. Юрченя //Журн. вушних, носових і горлових хвороб. - 2016. - № 5. - С. 103.

3. Байрак Д. М. "Морские" наружные отиты / Д. М.Байрак, Н. С. Степанова, В. М. Гранкова // Журн. вушних, носових і горлових хворо6. - 2016. - № 5. - С. 4-5.

4. Свистушкин В. М. Современные принципы лечения и профилактики заболеваний наружного уха / В. М. Свистушкин, Д. М. Мустафаев // Вестн. оторинола-

рингологии: научно-практический журнал. - 2013. № 4. - С. 67-71.

5. Гострий зовнішній отит. Рекомендації Американської академії отоларингології - хірургії голови та шиї (2014р.) // Дитячий лікар. - 2015. - № 2. - С. 59-62.

6. Serrano L. Association between atopic dermatitis and extracutaneous bacterial and mycobacterial infections: A systematic review and meta-analysis / L. Serrano, K. R. Patel, J. I. Silverberg // J. Am. Acad. Dermatol. -2019No. 80 (4). - P. 904-912. DOI: 10.1016/j.jaad.2018.11.028.

7. Gore J. Otitis externa / J. Gore // JAAPA. - 2018 No. 31 (2). - P. 47-48. DOI: 10.1097/01.JAA.0000529781. $69812.8 \mathrm{e}$.

\title{
REFERENCES
}

1. Fedotova, O.V., \& Shadrin, G.B. (2016). Sovremennyy vzglyad na lecheniye diffuznogo naruzhnogo otita [A modern view of the treatment of diffuse external otitis media]. Vestnik otorinolaringologii - Bulletin of Otorhinolaryngology, 81 (3), 51-53 [in Russian].

2. Piontkovskaya, M.B., \& Yurchenya, Yu.V. (2016). Khronicheskiye naruzhnyye otity: voprosy sportivnoy profpatologii u detey i podrostkov [Chronic otitis externa: issues of sports occupational pathology in children and adolescents]. Zhurn. vushnykh, nosovykh i horlovykh khvorob-Journal of Ear, Nose and Throat Diseases, 5c, 103 [in Russian].

3. Bayrak, D.M., Stepanova, N.S., \& Grankova, V.M. (2016). "Morskiye" naruzhnyye otity ["Marine" external otitis]. Zhurn. vushnykh, nosovykh i horlovykh khvorob - Journal of Ear, Nose and Throat Diseases, 5c, 4-5 [in Russian].

4. Svistushkin, V.M., \& Mustafayev, D.M. (2013). Sovremennyye printsipy lecheniya i profilaktiki zabolevaniy

naruzhnogo ukha [Modern principles of treatment and prevention of diseases of the external ear]. Vestn. otorinolaringologii: nauchno-prakticheskiy zhurnal - Bulletin of Otorhinolaryngology: A Scientific and Practical Journal, 4, 67-71 [in Russian].

5. (2015). Hostryi zovnishnii otyt. Rekomendatsii Amerykanskoi akademii otolarynholohii - khirurhii holovy ta shyi [Acute otitis externa. Recommendations of the American Academy of Otolaryngology - Head and Neck Surgery]. Dytiachyi likar - Pediatrician, 2, 59-62 [in Ukrainian].

6. Serrano, L., Patel, K.R., \& Silverberg, J.I. (2019). Association between atopic dermatitis and extracutaneous bacterial and mycobacterial infections: A systematic review and meta-analysis. J. Am. Acad. Dermatol., 80 (4), 904912. DOI: $10.1016 /$ j.jaad.2018.11.028.

7. Gore, J. (2018). Otitis externa. JAAPA, 31 (2), 47-48. DOI: 10.1097/01.JAA.0000529781.69812.8e.

\section{ОСОБЕННОСТИ ТЕЧЕНИЯ ВНЕШНЕГО ДИФФУЗНОГО ОТИТА ПРИ АТОПИЧЕСКОМ ДЕРМАТИТЕ}

\author{
๑А. Е. Кононов, И. Я. Пугач
}

\author{
Национальная медицинская академия последипломного образования имени П. Л. Шупика
}

РЕзюМЕ. Диффузное воспаление наружного слухового прохода - диффузный наружный отит (ДзО) достаточно распространенное заболевание уха. С ним сталкиваются как врачи-отоларингологи, так и врачи общего профиля. Этиологические факторы могут быть различными: аэробная, анаэробная флора, грибы. Иногда ДЗо бывают фоне атопического дерматита (АД) у детей. АД связан с повышенной бактериальной колонизацией и инфекцией кожи. Заболевание имеет двустороннюю локализацию, рецидивирующее течение и зависит от обострения атопического дерматита. Бактериальные посевы выделений проявляют постоянную смену флоры, в зависимости от проводимого лечения. Мы обследовали и пролечили 2 больных сочетанной патологией. В обоих случаях проведено лечение местными комбинированными препаратами. Следовательно, своевременная диагностика этого вида диффузного наружного отита на фоне атопического дерматита позволяет провести адекватную терапию

КЛЮчЕВЫЕ СЛОВА: диффУзный наружный отит; атопический дерматит; семейный врач; дети. 
๑O. E. Kononov, I. Ya. Pugach

\section{P. Shupyk National Medical Academy of Postgraduate Education}

SUMMARY. Diffuse inflammation of the external auditory canal - diffuse otitis externa (DOE) is a fairly common ear disease $(1,2)$. It is faced by both otolaryngologists and general practitioners. Etiological factors can be various: aerobic, anaerobic flora, fungi. Sometimes DOE occurs on the background of atopic dermatitis (AD) in children. AD is associated with increased bacterial colonization and skin infection. The disease has bilateral localization, recurrence and depends on the exacerbation of atopic dermatitis. Bacterial cultures of secretions show a constant change of flora, depending on the treatment. We examined and treated 2 patients with combined pathology. In both cases, treatment with local combination drugs. Therefore, timely diagnosis of this type of diffuse otitis externa on the background of atopic dermatitis allows for adequate therapy.

KEY WORDS: diffuse external otitis media; atopic dermatitis; family doctor; children. 